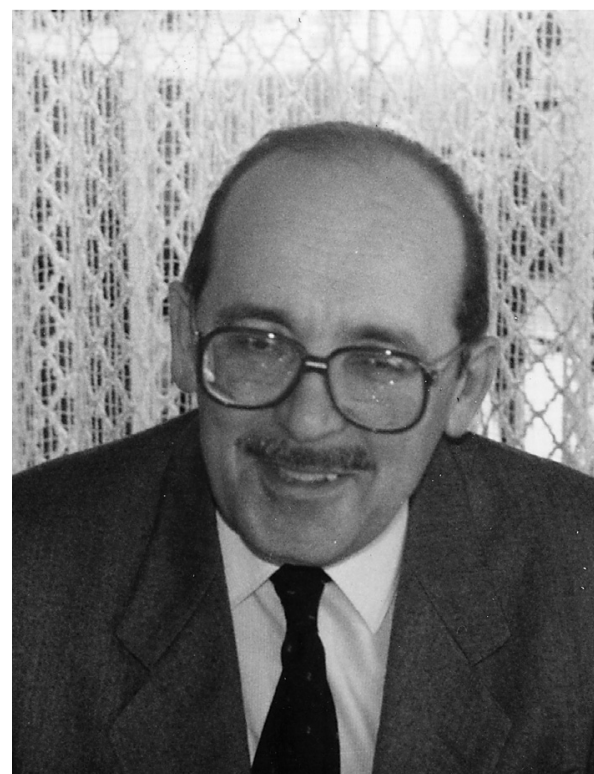

\title{
Manuel Gómez Larrañeta (Tolosa, 1924 - Vigo, 2012)
}

With a degree in Natural Sciences from the University of Barcelona (1946) and a PhD from the same university (1965), Manuel Gómez Larrañeta joined the Fisheries Research Institute when it was founded in 1949 and contributed greatly to its development, sharing the enthusiasm and the efforts of a handful of pioneers. He was laboratory director of Castellón (1954-1967) and Vigo (1967-1979). While he was in Vigo, the current building was constructed. Thanks to his foresight and determination the laboratory, built when there was a staff of only 25 , is now able to house over 250 .

The international seminar sponsored by the FAO in Lowestoft, England in 1957, where the most advanced analytical methods of the time were presented, was a turning point for Dr. Larrañeta. He was the first Spaniard to learn the techniques of fish stock dynamics, and pioneered their implementation and dissemination in Spain and later in Latin America, beginning with Chile, where he taught for one year at the Pontifical Catholic University in Santiago. He applied this methodology in the Castellón Experimental Trawling Plan (1961-1967), showing that it improved fishing yields. Dr. Larrañeta thus became a passionate scholar and eventually a master of fisheries science and management. After his retirement in 1989 he continued to attend the Institute for ten years, preparing his more complete theoretical work, which deals with the stockrecruitment relationship in fish.
He hated improvisation: he needed to work on every issue and think it over before talking about it, so when he did, he appeared confident and strong. He worked silently and tenaciously. As a "good Basque" from Tolosa, which he boasted about, he was indefatigable in any endeavour. Though he was realistic and conservative, he was always ready to join projects if he deemed them of interest, even though they seemed utopian. His participation in the Galician Fisheries Plan did not meet the full expectations; it was certainly too ambitious for the time, but these were the first steps in the scientific monitoring of the Galician fisheries. Through his many publications, his teaching and advice, and his direction of research projects, Dr. Larrañeta created a school and became a reference.

His professional life can be summed up as a "commitment". It was clear to him that his duty as a civil servant was to provide a service to society. This required him to fully commit himself to the science and the fishing industry, and to constantly keep abreast of scientific knowledge.

With Dr. Larrañeta we have lost another of those pioneers who founded the Fisheries Research Institute which, as he said, has become much more than was dreamed in the beginning. His legacy and his memory remain alive among us. Instituto Investigaciones Marinas, CSIC 